\title{
TP63 gene mutation in ADULT syndrome
}

\author{
Jeanne Amiel ${ }^{*, 1}$, Gaëlle Bougeard ${ }^{2}$, Christine Francannet ${ }^{3}$, Valérie Raclin ${ }^{1}$, \\ Arnold Munnich ${ }^{1}$, Stanislas Lyonnet ${ }^{1}$ and Thierry Frebourg ${ }^{2}$
}

${ }^{1}$ Département de Génétique, et Unité INSERM U-393, Hôpital Necker-Enfants Malades, 149, rue de Sèvres, 75743 Paris Cedex 15, France; ${ }^{2}$ INSERM EMI-9906, Faculté de Médecine et de Pharmacie, IFRMP, 76183 Rouen Cedex, France; ${ }^{3}$ Unité de Génétique, Département de Pédiatrie, Hôtel Dieu, 63003 Clermont-Ferrand Cedex, France

TP63 gene mutations have recently been shown to be disease causing in EEC and SHFM. Two other overlapping syndromes with ectrodactyly as a major feature, have been mapped to chromosome $3 q 27$ close by the TP63 locus, namely the LMS and ADULT syndromes. Here, we report on a missense TP63 gene mutation in an isolated ADULT syndrome case. This finding widens the spectrum of abnormalities to be ascribed to TP63 gene in human and emphasise on the variable roles of the different Tp63 isotypes. European Journal of Human Genetics (2001) 9, 642-645.

Keywords: ADULT syndrome; EEC syndrome; SHFM; TP63; limb abnormality

\section{Introduction}

The acronym ADULT (acro-dermato-ungual-lacrimal-tooth, MIM 103285) defines a rare autosomal dominant syndrome characterised by ectrodactyly, onychodysplasia, hypodontia, obstruction of lacrimal ducts and excessive freckling. ${ }^{1}$ The ADULT syndrome gene has recently been localised to chromosome 3q27 where two others syndromic forms of ectrodactyly have been mapped, namely the ectodermal ectrodactyly clefting (EEC3, MIM 604292) 2,3 $^{2,3}$ and limb mammary syndromes (LMS, MIM 603543). ${ }^{4}$ Because $p 63^{-1-}$ knock out mice show the association of major limb defect with absence of mammary, lacrimal, salivary glands and eyelids, ${ }^{5}$ the human TP63 gene, mapping to $3 \mathrm{q} 27$, was considered as a strong candidate gene in those conditions. Eventually, TP63 mutations were identified in both unrelated EEC cases and non syndromic split-hand-foot malformation (SHFM, MIM 183600) but not in the LMS syndrome. ${ }^{3,6,7}$ Here we report a TP63 missense mutation in an isolated case of ADULT syndrome.

*Correspondence: J Amiel, Département de Génétique, Hôpital NeckerEnfants Malades, 149, rue de Sèvres, 75743 Paris Cedex 15, France. Tel: +331444951 64; Fax: +331444951 50; E-mail: amiel@necker.fr Received 11 December 2000; revised 6 March 2001; accepted 1 May 2001

\section{Material and methods}

The patient, a female, is the elder child of healthy, unrelated parents. She was term born with low birth parameters (BW: 2500 g, BL: $46.5 \mathrm{~cm}$, OFC: $34 \mathrm{~cm}$ ). Growth and psychomotor development were in the normal range. She was first referred at 10.5 years of age for absent nipples. On examination, additional findings were observed, namely: (i) feet abnormalities with hypoplastic, over-riding toes, cutaneous 2-3 syndactyly and hypoplastic, discoloured toe nails; (ii) hands abnormalities with bilateral single palmar crease and Vth finger clinodactyly; (iii) freckling of the face, neck and chest, and; (iv) mild dysmorphic features with fine hair, malar hypoplasia, small mouth and multiple oral frenula (Figure $1 \mathrm{a}-\mathrm{d})$. Sweating and tears were normal. X-rays of hands and feet confirmed Vth fingers clinodactyly and hypoplastic toes (Figure 1e and f). Blood karyotype showed normal chromosomes, 46,XX.

Genomic DNA of the patient was extracted from leucocytes according to standard protocols. The coding region of the TP63 gene, exons 2-15, was PCR-amplified using primers described elsewhere. ${ }^{8}$ PCR was performed in a $50 \mu \mathrm{L}$ volume containing $100 \mathrm{ng}$ of genomic DNA, $1.5 \mathrm{mM} \mathrm{MgCl}_{2}, 200 \mu \mathrm{M}$ dNTPs, $0.5 \mu \mathrm{M}$ of each primer and 1 unit of Taq DNA polymerase $\left(\right.$ Eurobio $^{\mathrm{R}}$ ). After a denaturation of $3 \mathrm{~min}$ at $95^{\circ} \mathrm{C}$, the PCR consisted of 10 cycles of $10 \mathrm{~s}$ at $94^{\circ} \mathrm{C}, 10 \mathrm{~s}$ at $60^{\circ} \mathrm{C}$ (with a decrease of $1^{\circ} \mathrm{C}$ per cycle), and $10 \mathrm{~s}$ at $72^{\circ} \mathrm{C}$, then 35 cycles of $10 \mathrm{~s}$ at $94^{\circ} \mathrm{C}, 10 \mathrm{~s}$ at $50^{\circ} \mathrm{C}$, and $10 \mathrm{~s}$ at $72^{\circ} \mathrm{C}$ and was followed by a final extension of $7 \mathrm{~min}$ at $72^{\circ} \mathrm{C}$. After 

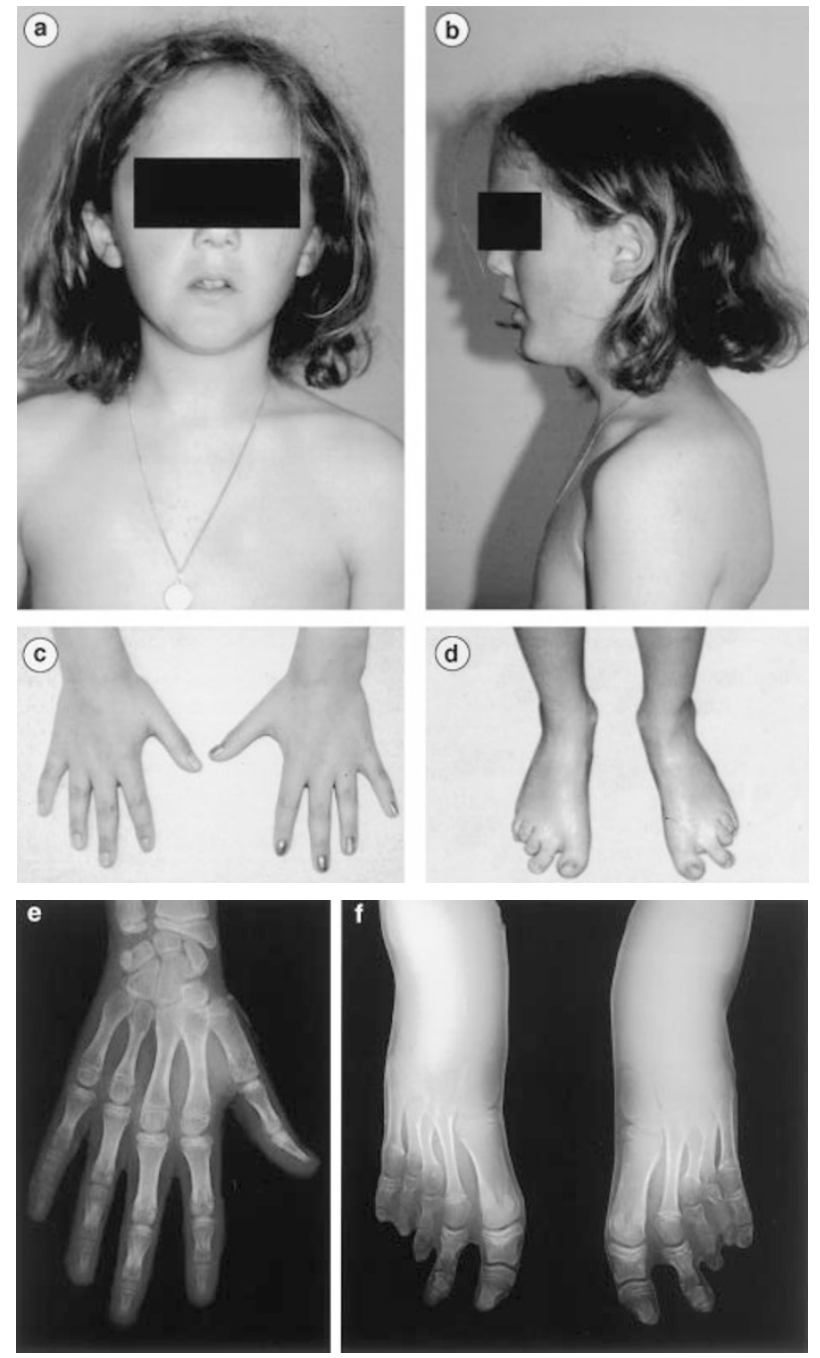

Figure 1 Patient with ADULT syndrome. (a) Note absent nipples, fine hair and small mouth. (b) Note malar hypoplasia. (c) Note bilateral clinodactyly of the Vth finger. (d) Note hypoplastic, over-riding toes, cutaneous $2-3$ syndactyly and hypoplastic, discoloured toe nails. (e) X-ray of the left hand at the age of 11 years. Note clinodactyly of the Vth finger. (f) X-ray of the feet at the age of 11 years. Note bilateral hypoplasia of toes III, IV and V.

purification of the PCR products using QIAquick Gel Extraction Kit (Qiagen), sequencing analysis was performed using the PRISM Ampli Taq FS Ready Reaction Dye Terminators sequencing kit (PE Applied Biosystems) and a PE Applied Biosystems 377 automated DNA sequencer.

\section{Results}

TP63 sequence analysis revealed an heterozygous nucleotidic transversion at position 16 in exon $3^{\prime}(\mathrm{A}>\mathrm{C})$, resulting in the substitution of a conserved asparagin by an histidine at codon $6(\mathrm{~N} 6 \mathrm{H})$. The nucleotidic variation was inherited from the healthy father and was absent from a panel of 250 control chromosomes (Figure 2A).

\section{Discussion}

The TP63 gene encodes six main isotypes with variable abilities to transactivate TP53 target genes involved in apoptosis and/or cell cycle arrest. In mice, p63 is expressed in the apical ectodermal ridge, branchial arches and epideral appendage (Yang et al., 1999). All six Tp63 isotypes contain a DNA binding domain while only three isotypes contain a transactivation domain (TA, Figure 2B)..$^{3,9}$ The mutation

A ATGTTGTACCTGGAAABCA AGCCCAGACTC
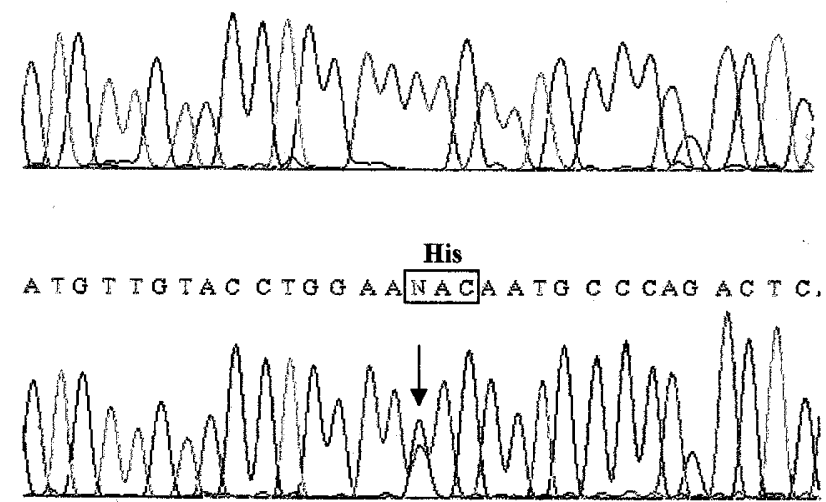

B

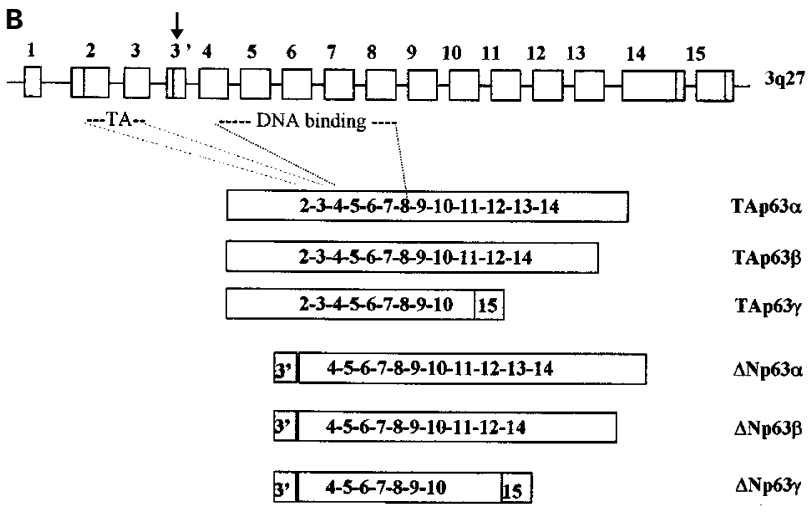

Figure 2 (A) N6H mutation of the TP63 gene (exon $3^{\prime}$ ). The TP63 gene was PCR-amplified from genomic DNA and directly sequenced. Sequences observed in the proband (bottom) and in a control (top) are shown. Heterozygous mutation in the ADULT patient is indicated by an arrow $(\mathrm{N})$. The predicted amino-acid change is indicated above the nucleotide sequence. (B) The TP63 isotypes. The N6H mutation reported is indicated by an arrow. TA: trans activation domain, DNA binding: DNA binding domain. 
Table 1 Clinical features in four overlapping syndromes

\begin{tabular}{|c|c|c|c|c|c|}
\hline & SHFM & EEC (TP63) & LMS & $A D U L T$ & $\angle A D D$ \\
\hline Limbs abnormalities & + & + & $\begin{array}{l}+ \\
(75 \%)\end{array}$ & $\begin{array}{l}+ \\
\text { (incomplete penetrance) }\end{array}$ & $\stackrel{+}{\text { (radial ray) }}$ \\
\hline Ectrodactyly & + & + & + & + & - \\
\hline Syndactyly & + & + & + & + & + \\
\hline Ectodermal dysplasia & - & + & $\begin{array}{l}+ \\
\text { (30\%, hypohydrosis) }\end{array}$ & $\stackrel{ \pm}{\text { (freckling) }}$ & - \\
\hline $\mathrm{CL} / \mathrm{P}$ & - & + & $\begin{array}{l}+ \\
(20 \%, C P / \text { bifid uvula })\end{array}$ & - & occasional \\
\hline Teeth abnormalities & - & + & $\begin{array}{l}+ \\
(15 \%, \text { hypodontia) }\end{array}$ & $\begin{array}{l}+ \\
\text { (hypodontia) }\end{array}$ & $\begin{array}{l}+ \\
\text { (hypodontia, abnormal shape) }\end{array}$ \\
\hline Lacrimal ducts atresia & - & \pm & $\begin{array}{l}+ \\
(50 \%)\end{array}$ & + & + \\
\hline Nipple/breast hypoplasia & - & - & $+(100 \%) /+$ & $+/+$ & - \\
\hline Hair abnormalities & - & $\begin{array}{l}+ \\
\text { (sparse) }\end{array}$ & - & $\begin{array}{l}+ \\
\text { (fine) }\end{array}$ & - \\
\hline Nails abnormalities & - & $?$ & $\begin{array}{l}+ \\
\text { (30\%, dysplasia) }\end{array}$ & $\begin{array}{l}+ \\
\text { (dysplasia) }\end{array}$ & $\begin{array}{l}+ \\
\text { (dysplasia) }\end{array}$ \\
\hline Ears abnormalities & - & - & - & - & $\begin{array}{l}+ \\
\text { (cup shape) }\end{array}$ \\
\hline
\end{tabular}

Trait penetrance is given in brackets.

reported here affects exon $3^{\prime}$ present only in the isotypes lacking the transactivation domain of the Tp63 protein $(\Delta \mathrm{N}$ $\mathrm{p} 63 \alpha, \beta$ and $\gamma$ ). Conversely, so far, all but one mutation detected in EEC3 patients are within the DNA binding domain of the protein. ${ }^{3,6,7} \Delta \mathrm{N}-\mathrm{p} 63 \alpha$, the major TP63 isotype in basal cells of epithelial tissues, has been shown in vitro to have a dominant-negative effect towards transactivation activities mediated by TP53 and TA-p63. ${ }^{3,9}$ Therefore, although we cannot exclude that the $\mathrm{N} 6 \mathrm{H}$ mutation is a rare variant, one may hypothesise that ADULT syndrome results in a release of the dominant-negative control of $\Delta \mathrm{N}$ isotypes.

The TP63 N6H mutation that we identified was inherited from the healthy father in whom frecking of the back and shoulders was the only feature of ADULT syndrome that could be noticed. DNA of the proband's paternal grand parents was not available for DNA analysis. Thus, while we cannot exclude mosaic in the proband's father, incomplete penetrance is the most likely hypothesis. Non penetrance in obligate carriers has been documented in families with EEC $3,{ }^{6}$ as well as in the four generations family with ADULT syndrome reported by Propping and Zerres. ${ }^{1}$ In this family, watch glass nails was the only feature in an affected male, and four out of eight affected individuals had normal hands and mild abnormalities of the feet (cutaneous syndactyly or short second toe). Van Bokhoven and coworkers mention a TP63 gene mutation in an ADULT syndrome case. Whether this is a sporadic or familial case is not specified. ${ }^{10}$

Finally, there is a considerable overlap between EEC, LMS, ADULT and lacrimo-auriculo-dento-digital syndromes ((LADD, MIM 149730, Table 1). Both linkage analysis in a three generations family described elsewhere, ${ }^{11}$ and direct
DNA sequencing in an isolated case excluded TP63 as the disease causing gene in LADD (personal data not shown). LMS and ADULT syndromes share features in accordance with the pattern of expression of TP63 in mice that are only occasionally found in EEC3, namely lacrimal duct atresia and breast/nipple hypoplasia. However, no nucleotidic variation in the TP63 binding domain could be identified in LMS. It is therefore tempting to speculate that LMS, as ADULT syndrome, might result from an as yet unidentified defect of the Tp63 isotypes lacking the transcriptional domain, inducing an alteration of the regulation of the TP63 function.

In conclusion, we showed that ADULT syndrome could be ascribed to TP63 gene mutation. This finding allows the lumping of two clinical entities and widens the spectrum of malformations resulting from TP63 mutations in human.

\section{References}

1 Propping P, Zerres K: ADULT-syndrome: an autosomal-dominant disorder with pigment anomalies, ectrodactyly, nail dysplasia, and hypodontia. Am J Med Genet 1993; 45: 642-648.

2 Propping P, Friedl W, Wienker TF, Uhlhaas S, Zerres K: ADULT syndrome allelic to limb mammary syndrome (LMS)? Am J Med Genet 2000; 90: 179-182.

3 Celli J, Duijf P, Hamel BC et al: Heterozygous germline mutations in the P53 homolog P63 are the cause of EEC syndrome. Cell 1999; 99: 143-153.

4 van Bokhoven $\mathrm{H}$, Jung M, Smits AP et al: Limb Mammary syndrome: a new genetic disorder with mammary hypoplasia, ectrodactyly, and other hand/foot anomalies maps to human chromosome 3q27. Am J Hum Genet 1999; 64: 538-546.

5 Yang A, Schweitzer R, Sun D et al: p63 is essential for regenerative proliferation in limb, craniofacial and epithelial development. Nature 1999; 398: $714-718$. 
6 Ianakiev P, Kilpatrick MW, Toudjarska I, Basel D, Beighton P, Tsipouras P: Split-hand/split foot malformation is caused by mutations in the p63 gene on 3q27. Am J Hum Genet 2000; 67: $59-66$.

7 Wessagowit V, Mellerio JE, Pembroke AC, McGrath JA: Heterozygous germline missense mutation in the p63 gene underlying EEC syndrome. Clin Exp Dermatol 2000; 25: 441-443.

8 Hagiwara K, McMenamin MG, Miura K, Harris CC: Mutational analysis of the $p 63 / p 73 L / p 51 / p 40 / C U S P / K E T$ gene in human cancer cell lines using intronic primers. Cancer Res 1999; 59 4165 - 4169.

9 Yang A, Kaghad M, Wang Y et al: p63, a p53 homolog at 3q27-29, encodes multiple products with transactivating, death-inducing, and dominant-negative activities. Mol Cell 1998; 2: $305-$ 316.
10 Van Bokhoven H, Mc Grath JA, Fuijf P et al: P63 mutations in the EEC, Hay-Wells, ADULT syndromes and in split hand/foot malformation reveals a genotype-phenotype correlation. Am J Hum Genet 2000; 67: 149.

11 Francannet C, Vanlieferinghen P, Dechelotte P, Urbain MF, Campagne D, Malpuech G: LADD syndrome in five members of a three-generation family and prenatal diagnosis. Genetic Couns 1994; 5: $85-91$. 